\title{
Groundwater arsenic and fluoride in Rajnandgaon District, Chhattisgarh, northeastern India
}

\author{
Khageshwar Singh Patel ${ }^{1} \cdot$ Bharat Lal Sahu ${ }^{1}$ Nohar Singh Dahariya ${ }^{1}$. \\ Amarpreet Bhatia $^{2} \cdot$ Raj Kishore Patel $^{3}$ - Laurent Matini ${ }^{4}$ - Ondra Sracek ${ }^{5}$. \\ Prosun Bhattacharya ${ }^{6}$
}

Received: 22 March 2015/Accepted: 6 October 2015/Published online: 21 December 2015

(C) The Author(s) 2015. This article is published with open access at Springerlink.com

\begin{abstract}
The groundwater of Ambagarh Chouki, Rajnandgaon, India, shows elevated levels of $\mathrm{As}$ and $\mathrm{F}^{-}$, frequently above the $\mathrm{WHO}$ guidelines. In this work, the concentrations of As, $\mathrm{F}^{-}, \mathrm{Na}^{+}, \mathrm{Mg}^{2+}, \mathrm{Ca}^{2+}, \mathrm{Cl}^{-}, \mathrm{SO}_{4}{ }^{2-}$, $\mathrm{HCO}_{3}{ }^{-}, \mathrm{Fe}$, dissolved organic carbon (DOC) and dissolved inorganic carbon (DIC) in the groundwater of Ambagarh Chouki are described. The sources of dissolved components in the groundwater are investigated using the cluster and factor analysis. Five factors have been identified and linked to processes responsible for the formation of groundwater chemistry. High concentrations of dissolved As seems to be linked to high concentrations of DOC, suggesting reductive dissolution of ferric oxyhydroxides as arsenic mobilization process. Fluoride is found in shallow depth water, presumably as a consequence of evaporation of water and removal of $\mathrm{Ca}^{2+}$ by precipitation of carbonates.
\end{abstract}

Keywords Arsenic - Fluoride - Trace element . Groundwater

Khageshwar Singh Patel

patelkhageshwarsingh@gmail.com

1 School of Studies in Chemistry, Pt. Ravishankar Shukla University, Raipur, India

2 Department of Chemistry, NIT, Raipur, India

3 Department of Chemistry, NIT, Rourkela 769 008, India

4 Department of Exact Sciences, Marien Ngouabi University, Brazzaville, Congo

5 Department of Geology, Faculty of Science, Palacký University, Listopadu, Olomouc, Czech Republic

6 KTH-International Groundwater Arsenic Research Group, Department of Land and Water Resources Engineering, Royal Institute of Technology, Stockholm, Sweden

\section{Introduction}

Arsenic and fluoride are toxic elements presenting serious hazards for human health (Hileman 1988; Flanagan et al. 2012). The elevated concentrations of As in groundwater observed in different regions of South Asia is of an increasing concern because a large population is exposed to inorganic As through drinking water, contaminated food, dust, etc. (Chatterjee and Mukherjee 1999; Chakraborti et al. 2003; Acharyya et al. 2005; Patel et al. 2005; Agusa et al. 2006; Baig et al. 2009; Chauhan et al. 2009; Chatterjee et al. 2010; Kar et al. 2010; Kumar et al. 2010; Shukla et al. 2010; Winkel et al. 2011; Rodríguez-Lado et al. 2013). The fluoride contamination of groundwater was reported in several parts of India (Dutta et al. 2006; Meenakshi and Maheshwari 2006; Singh et al. 2007; Sankararamakrishnan et al. 2008; Suthar et al. 2008; Kundu and Mandal 2009; Yadav et al. 2009; Jha et al. 2010; Reddy et al. 2010). The environment of Ambagarh Chouki, Rajnandgaon, India has high levels of As (Acharyya et al. 2005; Patel et al. 2005; Shukla et al. 2010). Consumption of the contaminated water is the principal exposure pathway of As and $\mathrm{F}^{-}$for humans in this region.

The groundwater As contamination in the Ambagarh Chouki block situated in the Rajnandgaon district of the state of Chhattisgarh was first reported by Chakraborti et al. (1999). Groundwater samples from 146 sites, Public Health Engineering Department (PHED) tube wells and dug wells in 22 villages of this block were analyzed. Arsenic concentration in tube well water was elevated above the WHO guideline by a factor of more than 10 with concentrations reaching $520 \mu \mathrm{g} 1^{-1}$, whereas in the dug wells (general depth less than $50 \mathrm{~m}$ ) As concentrations were as high as $880 \mu \mathrm{g} 1^{-1}$. Medical study in that village indicated $42 \%$ of adults and $9 \%$ of children are suffering from arsenical skin 
lesions. Also, epidemiological studies indicated high concentrations of As in urine, hair and nail in respective 89, 75 and $91 \%$ of the village population. In the same area, i.e., at village Kourikasa, Rajnandgaon, district Chhattisgarh, Central India, an extensive study on the groundwater As over a period of 3 years has been conducted (1998-2000) based on the monitoring of As concentrations in hand pumps and dug wells in the region (Pandey et al. 2002).

Arsenic contamination in groundwater at variable concentration levels occurs at small patches in the Ambagarh Chouki block of Rajnandgaon district of the state of Chhattisgarh in Central India (Fig. 1a). Tube well waters are affected by high concentrations of As in some areas confined to $\mathrm{N}-\mathrm{S}$ trending Dongargarh-Kotri rift zone which exposes the early Proterozoic metavolcanic rocks and co-magmatic granite (Sarkar 1957; Krishnamurthy et al. 1988; Acharyya et al. 2001; Acharyya 2002).

In the Ambagarh Chouki area, there is a rocky basement covered by alluvium, colluvium, and soil. Tube wells tap groundwater in the fracture system in bedrock. Previous studies (Pandey et al. 1999; Deshpande et al. 2010), mentioned panning for gold in the area and the presence of mine dumps around Bodal $\left(20^{\circ} 40^{\prime} \mathrm{N}\right.$ and $\left.80^{\circ} 46^{\prime} \mathrm{E}\right)$, which are located close to Kaurikasa $\left(20^{\circ} 43^{\prime} 9^{\prime \prime} \mathrm{N}\right.$ and $\left.80^{\circ} 44^{\prime} 7^{\prime \prime} \mathrm{E}\right)$, village where severe As-contamination occurs. It was assumed that these factors may have some connection to the source of As in groundwater. Some works also postulated that water in the principal river Sivnath, which flows through the As affected groundwater area, might be contaminated. Thus, Raipur, the capital city of Chhattisgarh state and townships like Rajnandgaon and Drug, located downstream, are likely to be at risk (Pandey et al. 1999). Later studies (Acharyya et al. 2001; Acharyya 2002) found that As pollution of groundwater is restricted to small isolated patches at village scale, and the Sivnath river water has As concentration below $10 \mu \mathrm{g} \mathrm{l}^{-1}$. The Chhattisgarh basin, located to the east of the Dongargarh rift zone, and exposing mid-late Proterozoic platform-type clastic and carbonate sediments, is totally free of As contamination. Recent investigations (Pandey et al. 2006; Deshpande et al. 2010; Shukla et al. 2010) in the Kourikasa, Rajnandgaon, Chhattisgarh, found elevated concentrations of As in the wells located in acid volcanic rocks, close to shear zones as well as in granites.

The aim of the study is to consolidate the information and database on the groundwater resources for exploitation of As and $\mathrm{F}^{-}$-safe drinking water in the affected hotspots in selected areas of Rajnandgaon district, Central India. The specific goal of this project was to develop an approach for targeting As and $\mathrm{F}^{-}$-safe aquifers for drinking purposes to: (1) identify As and other trace element baselines in the region, and (2) to develop a scientific database for the identification of $\mathrm{As}$ and $\mathrm{F}^{-}$-safe aquifers. Within the framework of this project, we also aim to use the hydrogeological and geochemical data as a basis for the evaluation of the risks associated with these aquifers, and thereby their sustainability as safe drinking water source.

\section{Materials and methods}

\section{Study area}

The Kourikasa area covers over $\approx 500 \mathrm{~km}^{2}\left(20^{\circ} 43^{\prime} 9^{\prime \prime} \mathrm{N}\right.$ and $80^{\circ} 44^{\prime} 7^{\prime \prime} \mathrm{E}$ ). The sampling locations are shown in Fig. 1b. Total 20 ground water samples in each season from this region were collected in post-monsoon period, November 2010 and pre-monsoon period, May, 2011 as described in the literature (Nielsen and Nielsen 2006).

\section{Analysis}

The field parameters, i.e., $\mathrm{pH}$, temperature $(\mathrm{T})$, electrical conductance (EC), dissolved oxygen (DO) and reduction potential (RP) were measured on site. The total hardness (TH) and alkalinity values were analyzed by titration methods (Nollet and De Gelder 2007 ). The total dissolved solid (TDS) value was determined by evaporation of filtered samples (through glass fiber filter) and drying (APHA 2005).

GBC AAS932 equipped with the HG3000 hydride generator was used for the determination of total As. Detection limit of $1 \mu \mathrm{g} 1^{-1}$ As was routinely achieved and precision for three replicate measurements was better than $\pm 1.0 \%$.

The CHNSO-IRMS Analyzer by SV Instruments Analytica Pvt. Ltd. was used for analysis of the dissolved organic carbon (DOC) and dissolved inorganic carbon (DIC). The total dissolved carbon (TDC) was oxidized with $\mathrm{O}_{2}$ at $1020{ }^{\circ} \mathrm{C}$ with constant helium flow using $\mathrm{WO}_{3}$ as catalyst. The resulting $\mathrm{CO}_{2}$ was monitored by the conductivity detector. The DOC content was determined by oxidation of the prior $\mathrm{HCl}$-treated water sample as described above. The DIC content was computed by subtracting the DOC from the TDC (DIC = TDC - DOC).

The Dionex DX120 Ion Chromatograph (Dionex Corporation, Sunnyvale, CA, USA) equipped with anion separation column (AS9-HC, $250 \times 4 \mathrm{~mm}$ ), cation separation column $(\mathrm{CS} 12 \mathrm{~A}, 250 \times 4 \mathrm{~mm})$ and conductivity detector was used for analysis of the principal ions, i.e., $\mathrm{Na}^{+}, \mathrm{K}^{+}$, $\mathrm{Mg}^{2+}, \mathrm{Ca}^{2+}, \mathrm{Cl}^{-}, \mathrm{SO}_{4}{ }^{2-}$ and $\mathrm{NO}_{3}{ }^{-}$.

Fluoride was determined by Orion Ion Analyzer-720 equipped with the ion-selective electrode using the buffer. The buffer (TISAB-III) solution was added to both samples and standards. TISAB-III was prepared by dissolving $300 \mathrm{~g}$ sodium citrate $(\mathrm{FW}=294), 22 \mathrm{~g}$ of 1,2-cyclohexanediamine $\mathrm{N}, \mathrm{N}, \mathrm{N}, \mathrm{N}-$ tetra-acetic acid (CDTA) and $60 \mathrm{~g}$ of $\mathrm{NaCl}$ in a volume of $1000 \mathrm{ml}$ of water (pH 5.0-5.5). The 
Fig. 1 a Geological map of Rajnandgaon District in Chhattisgarh state of Central India with the location of Kourikasa village (right). b Sampling locations of groundwater in Kourikasa area, Rajnandgaon, CG, India
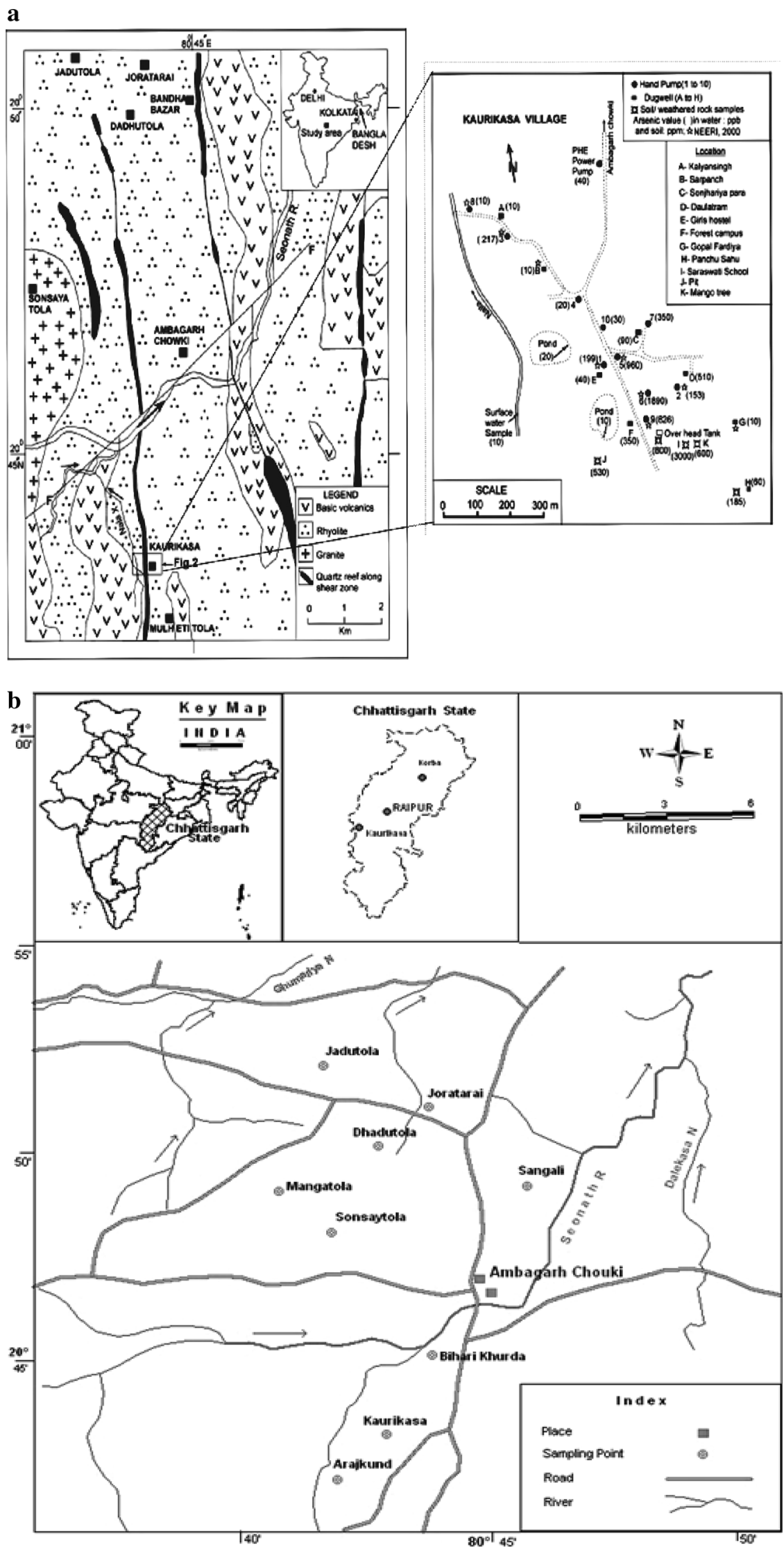
TISAB-III regulated, adjusted and masked the ionic strength of the solutions, the $\mathrm{pH}$ and interferences by polyvalent cations such as $\mathrm{Al}(\mathrm{III}), \mathrm{Fe}(\mathrm{III})$ and $\mathrm{Si}(\mathrm{IV})$, respectively. In the solution, CDTA formed stable complexes with polyvalent metal cations which were more stable than metal-fluoride complexes. The electrode was selective for the $\mathrm{F}^{-}$ions by several orders of magnitude.

The exchangeable sodium ratio (ESR), sodium hazard $(\mathrm{SH})$, magnesium hazard( $\mathrm{MH})$ and water quality index (WQI) were computed for rating of the water quality. The ESP, and SH values are calculated as follows:

$$
\begin{aligned}
& \mathrm{ESP}=\{(\mathrm{Na}) /(\mathrm{Ca}+\mathrm{Mg}+\mathrm{K}+\mathrm{Na})\} \times 100 \\
& \mathrm{SH}=(\{[\mathrm{Na}]+[\mathrm{K}]\} /\{[\mathrm{Na}]+[\mathrm{K}]+[\mathrm{Mg}]+[\mathrm{Ca}]\}) \\
& \quad \times 100
\end{aligned}
$$

where all ions are expressed in meq $1^{-1}$.

Magnesium plays important role in irrigation water, and magnesium hazard $(\mathrm{MH})$ is calculated using following equation.

$\left.\mathrm{MH}=\left\{\left[\mathrm{Mg}^{2+}\right] /\left[\mathrm{Mg}^{2+}\right]\right\}+\left[\mathrm{Ca}^{2+}\right]\right\} \times 100$

where all ions are expressed in $\mathrm{mol}^{-1}$.

Ten parameters, i.e., $\mathrm{pH}, \mathrm{EC}, \mathrm{DO}$, hardness, alkalinity, $\mathrm{Mg}^{2+}, \mathrm{Ca}^{2+}, \mathrm{Cl}^{-}, \mathrm{NO}_{3}{ }^{-}$and $\mathrm{SO}_{4}{ }^{2-}$ were selected for evaluation of WQI using the standard values recommended by BIS and WHO. The weighed arithmetic method was used for calculation of the WQI of the groundwater with the help of the following expression.

$\mathrm{WQI}=\Sigma q_{n} \mathrm{~W}_{n} / \Sigma \mathrm{W}_{n}$

where

$\mathrm{q}_{n}=100\left(V_{\mathrm{o}}-V_{\text {io }}\right) /\left(V_{\mathrm{s}}-V_{\text {io }}\right)$

$\mathrm{q}_{n}=$ Quality rating of the nth water quality parameter, $V_{n}=$ Estimated value of the $n$th parameter of a given water, $\mathrm{S}_{n}=$ Standard permissible value of the $n$th parameter, $V_{\text {io }}=$ Ideal value of the $n$th parameter of pure water (i.e., 0 for all other parameters except $\mathrm{pH}$ and dissolved oxygen (7.0 and $14.6 \mathrm{mg} \mathrm{l}^{-1}$, respectively), $W_{n}=$ Unit weight for the $n$th parameter, $K=$ Proportionality constant.

Multivariate statistics (i.e., Cluster and Factor analysis) was used to differentiate the water samples on the basis of their composition and origin (Simeonov et al. 2003; Boyacioglu and Boyacioglu 2008). The software STATISTICA 7.1 window was used for the statistical analysis.

\section{Results and discussion}

\section{Physical characteristics of tube well and groundwater}

The physico-chemical characteristics of the groundwater are summarized in Table 1. All tube wells in the study area are deeper, ranging from 52 to $90 \mathrm{~m}$. The age of tube wells was in the range of 1-20 Years. Temperature was ranging from 27.1 to $27.6{ }^{\circ} \mathrm{C}$ with a mean value of $27.3 \pm 0.2{ }^{\circ} \mathrm{C}$.

In this study, $\mathrm{pH}$ values of groundwater ranged from 6.4 to 7.9 with a mean value of $6.8 \pm 0.1$. The EC and TDS values ranged from 940 to $1427 \mu \mathrm{S} \mathrm{cm}^{-1}$ and 574 to $5373 \mathrm{mg} \mathrm{l}^{-1}$ with mean values of $1192 \pm 84 \mu \mathrm{S} \mathrm{cm}{ }^{-1}$ and $2323 \pm 595 \mathrm{mg} \mathrm{l}^{-1}$, respectively. The EC value correlated well $(r=0.88)$ with the sum of total concentration of groundwater ions, $\Sigma_{\text {ions }}$ (i.e., $\mathrm{Na}^{+}, \mathrm{K}^{+}, \mathrm{Mg}^{2+}, \mathrm{Ca}^{2+}, \mathrm{F}^{-}, \mathrm{Cl}^{-}$, $\mathrm{NO}_{3}{ }^{-}, \mathrm{SO}_{4}{ }^{2-}$ and $\mathrm{HCO}_{3}{ }^{-}$). Among 20 tube wells studied, the highest EC and TDS values were recorded in tube well no. 19. The mean EC and TDS value of groundwater in the studied area was found to be two- and fourfolds higher than the respective permissible limit of $300 \mu \mathrm{S} \mathrm{cm} \mathrm{cm}^{-1}$ and $500 \mathrm{mg} \mathrm{l}^{-1}$ (BIS 2003; WHO 2011). The RP and DO value of the water ranged from 240 to $392 \mathrm{mV}$ and 4.1 to $7.3 \mathrm{mg} \mathrm{l}^{-1}$ with mean values of $334 \pm 17 \mathrm{mV}$ and $4.8 \pm 0.3 \mathrm{mg} \mathrm{l}^{-1}$, respectively. The alkalinity of the water ranged from 209 to $742 \mathrm{mg} \mathrm{l}^{-1}$ with a mean value of $514 \mathrm{mg}^{-1}$ as $\mathrm{CaCO}_{3}$. The alkalinity value of water in all tube wells was found to be higher than the recommended value of $120 \mathrm{mg} \mathrm{l}^{-1}$ (BIS 2003; WHO 2011).

Hardness is a term relating to the concentrations of certain metallic ions in water, particularly $\mathrm{Mg}$ and $\mathrm{Ca}$, and is usually expressed as a concentration of dissolved calcite $\left(\mathrm{CaCO}_{3}\right)$. Durfor and Becker (1964) developed the following classification for water hardness: soft water, $0-60 \mathrm{mg} \mathrm{l}^{-1}$; moderately hard water, $61-120 \mathrm{mg}^{-1}$; hard water, $121-180 \mathrm{mg} \mathrm{l}^{-1}$; and very hard water, over $180 \mathrm{mg} \mathrm{l}^{-1}$. The total hardness of the water ranged from 103 to $529 \mathrm{mg}^{-1}$ with a mean value of $250 \pm 57 \mathrm{mg} \mathrm{l}^{-1}$. The water of $65 \%$ tube wells was found to be very hard $\left(>180 \mathrm{mg} \mathrm{l}^{-1}\right)$ due to higher $\mathrm{Mg}^{2+}$ and $\mathrm{Ca}^{2+}$ concentrations.

\section{Chemical characteristics of groundwater}

The chemical characteristics of the groundwater are summarized in Table 2. The DOC is a very important component in biogeochemical cycling of elements being an indicator for the groundwater pollution. The DOC and DIC concentration were relatively high, ranging from 107 to 1640 and 110 to $3120 \mathrm{mg} \mathrm{l}^{-1}$ with mean values of $695 \pm 198$ and $958 \pm 318 \mathrm{mg} \mathrm{l}^{-1}$, respectively. The higher DIC value in the groundwater of this region was observed, due to oxidation of DOC into $\mathrm{CO}_{2}$ to form carbonic acid. The DOC value was observed several folds higher than the recommended value of $2.0 \mathrm{mg} \mathrm{l}^{-1}$.

Very high concentration of $\mathrm{F}^{-}$in the groundwater of the studied area was observed due to dissolution of the fluoride minerals associated to the bed rocks. The $\mathrm{F}^{-}$concentration was found to be several folds higher than permissible limit of $1.5 \mathrm{mg} \mathrm{l}^{-1}$, ranging from $3.7-27$ with a mean value of 
Table 1 Physico-chemical characteristics of tube well and groundwater, November 2010

\begin{tabular}{|c|c|c|c|c|c|c|c|c|c|}
\hline S. No. & Location & Age & Depth & $\mathrm{T}\left({ }^{\circ} \mathrm{C}\right)$ & $\mathrm{pH}$ & $\mathrm{EC}$ & TDS & $\mathrm{RP}$ & DO \\
\hline 1 & Bharİ khurda & 11 & 65 & 27.3 & 6.8 & 1215 & 945 & 323 & 4.6 \\
\hline 2 & Bharİ khurda & 12 & 72 & 27.2 & 6.5 & 1150 & 670 & 368 & 4.9 \\
\hline 3 & Kaudi் kasa & 13 & 60 & 27.2 & 7.2 & 967 & 1116 & 352 & 4.3 \\
\hline 4 & Kaudİ kasa & 20 & 70 & 27.3 & 6.8 & 1321 & 1062 & 324 & 4.1 \\
\hline 5 & Kaudİ kasa & 17 & 60 & 27.3 & 7.0 & 1204 & 3567 & 307 & 5 \\
\hline 6 & Kaudİ kasa & 15 & 52 & 27.3 & 7.9 & 1105 & 1112 & 311 & 4.1 \\
\hline 7 & Arajkund & 15 & 60 & 27.3 & 7.2 & 1406 & 2615 & 319 & 4.6 \\
\hline 8 & Arajkund & 7 & 67 & 27.1 & 6.8 & 1280 & 4678 & 343 & 4.7 \\
\hline 9 & Kaudİ kasa & 13 & 75 & 27.3 & 6.7 & 1130 & 1007 & 364 & 4.4 \\
\hline 10 & Kaudİ kasa & 8 & 65 & 27.2 & 6.9 & 940 & 1989 & 271 & 4.4 \\
\hline 11 & Kaudİ kasa & 17 & 67 & 27.3 & 6.5 & 1040 & 3272 & 327 & 4.1 \\
\hline 12 & Sansaytola & 17 & 52 & 27.4 & 6.4 & 1148 & 3016 & 368 & 4.3 \\
\hline 13 & Sansaytola & 14 & 70 & 27.4 & 6.4 & 1070 & 3961 & 392 & 4.5 \\
\hline 14 & Sansaytola & 9 & 64 & 27.4 & 6.8 & 1167 & 1065 & 293 & 4.5 \\
\hline 15 & Dhadİtola & 8 & 60 & 27.5 & 6.6 & 1204 & 2472 & 240 & 6.2 \\
\hline 16 & Jorataraİ & 8 & 90 & 27.6 & 6.7 & 1160 & 2655 & 377 & 4.4 \\
\hline 17 & Jadutola & 1 & 75 & 27.4 & 7.1 & 1320 & 2492 & 352 & 4.8 \\
\hline 18 & Mangatola & 7 & 60 & 27.3 & 6.7 & 1427 & 2543 & 317 & 5.5 \\
\hline 19 & Mangatola & 9 & 75 & 27.5 & 6.8 & 1267 & 3110 & 368 & 7.3 \\
\hline 20 & Sangalİ & 1 & 54 & 27.3 & 7.1 & 1310 & 1100 & 373 & 4.4 \\
\hline
\end{tabular}

Table 2 Chemical characteristics $\left(\mathrm{mg} \mathrm{l}^{-1}\right)$ of groundwater, November 2010

\begin{tabular}{|c|c|c|c|c|c|c|c|c|c|c|c|c|c|}
\hline S. No. & $\mathrm{OC}$ & $\mathrm{CC}$ & $\mathrm{F}^{-}$ & $\mathrm{Cl}^{-}$ & $\mathrm{SO}_{4}{ }^{2-}$ & $\mathrm{NO}_{3}{ }^{-}$ & $\mathrm{HCO}_{3}^{-}$ & $\mathrm{Na}^{+}$ & $\mathrm{K}^{+}$ & $\mathrm{Mg}^{2+}$ & $\mathrm{Ca}^{2+}$ & $\mathrm{Fe}$ & $\mathrm{As}^{*}$ \\
\hline 1 & 310 & 310 & 4.5 & 17 & 16 & 3.1 & 207 & 16 & 1 & 11 & 38 & 1.32 & 220 \\
\hline 2 & 210 & 110 & 3.7 & 46 & 30 & 15 & 192 & 17 & 0.7 & 12 & 34 & 1.12 & 217 \\
\hline 3 & 460 & 160 & 5.7 & 43 & 22 & 17 & 281 & 36 & 0.9 & 26 & 64 & 1.68 & 510 \\
\hline 4 & 190 & 190 & 10 & 103 & 51 & 37 & 301 & 42 & 1.2 & 49 & 88 & 1.78 & 419 \\
\hline 5 & 1204 & 1604 & 19.5 & 89 & 60 & 20 & 366 & 42 & 11.8 & 47 & 104 & 2.25 & 985 \\
\hline 6 & 310 & 310 & 24 & 39 & 15 & 5.2 & 323 & 23 & 2.5 & 26 & 34 & 1.2 & 179 \\
\hline 7 & 970 & 970 & 11 & 78 & 62 & 4.5 & 348 & 40 & 1.1 & 42 & 88 & 1.14 & 208 \\
\hline 8 & 1020 & 3120 & 15 & 96 & 59 & 12 & 201 & 53 & 0.3 & 32 & 70 & 1.56 & 489 \\
\hline 9 & 330 & 330 & 12 & 50 & 30 & 14 & 146 & 24 & 1.4 & 22 & 48 & 1.62 & 376 \\
\hline 10 & 870 & 870 & 16 & 14 & 14 & 4.3 & 140 & 21 & 1.8 & 16 & 22 & 1.45 & 315 \\
\hline 11 & 1260 & 1360 & 8.7 & 78 & 45 & 17 & 329 & 80 & 15.3 & 13 & 66 & 1.8 & 620 \\
\hline 12 & 1070 & 1270 & 19.3 & 71 & 29 & 62 & 393 & 34 & 0.6 & 21 & 46 & 1.72 & 575 \\
\hline 13 & 1640 & 1640 & 12 & 67 & 37 & 51 & 385 & 51 & 0.4 & 28 & 50 & 1.9 & 826 \\
\hline 14 & 405 & 405 & 23.2 & 28 & 14 & 9.2 & 116 & 25 & 0.4 & 13 & 26 & 0.9 & 148 \\
\hline 15 & 110 & 1310 & 14 & 135 & 84 & 134 & 412 & 76 & 0.5 & 58 & 138 & 2.16 & 906 \\
\hline 16 & 560 & 1560 & 7.4 & 39 & 45 & 24 & 277 & 57 & 3 & 27 & 56 & 1.92 & 721 \\
\hline 17 & 1010 & 1010 & 8.3 & 21 & 43 & 2.7 & 327 & 27 & 0.7 & 12 & 30 & 2.06 & 805 \\
\hline 18 & 756 & 1015 & 14.6 & 128 & 72 & 73 & 299 & 31 & 0.5 & 64 & 90 & 1.65 & 587 \\
\hline 19 & 1103 & 1103 & 25.4 & 195 & 62 & 34 & 366 & 43 & 1.2 & 73 & 104 & 2.1 & 795 \\
\hline 20 & 107 & 507 & 27 & 39 & 17 & 17 & 305 & 27 & 0.7 & 15 & 38 & 1.25 & 210 \\
\hline
\end{tabular}

$*=\mu \mathrm{g} 1^{-1}$ 
$14.1 \pm 3.1$ (BIS 2003; WHO 2011). In $65 \%$ tube wells, the $\mathrm{F}^{-}$concentration was found above $10.0 \mathrm{mg} \mathrm{l}^{-1}$.

Chloride in ground water may originate from various sources including: the dissolution of halite. The recommended tolerance limit for $\mathrm{Cl}^{-}$reported is $250 \mathrm{mg} \mathrm{l}^{-1}$ (BIS 2003; WHO 2011). The concentration of $\mathrm{Cl}^{-}$in the groundwater ranged from 14 to $195 \mathrm{mg}^{-1}$ with a mean value of $69 \pm 20 \mathrm{mg} \mathrm{l}^{-1}$. The remarkably higher concentration of $\mathrm{Cl}^{-}$observed in the water of tube well nos. 4,15 , 18 and 19 may be due to sewage contamination. The concentration of $\mathrm{Na}^{+}$in the groundwater ranged from 16 to $80 \mathrm{mg} \mathrm{l}^{-1}$ with a mean value of $38 \pm 8 \mathrm{mg} \mathrm{l}^{-1}$. The ionic ratio of $\left[\mathrm{Na}^{+}\right] /\left[\mathrm{Cl}^{-}\right]$in the water ranged from 0.3 to 2.3 with a mean value of $1.1 \pm 0.3$. It indicates that sodium concentrations exceed chloride concentrations in many samples (45\%), suggesting dissolution of silicate minerals. The $\mathrm{K}^{+}$concentration in the water ranged from 0.3 to $15.3 \mathrm{mg} \mathrm{l}^{-1}$ with mean value of $2.3 \pm 1.8 \mathrm{mg} \mathrm{l}^{-1}$. The ionic ratio of $\left\{\mathrm{Na}^{+}\right] /\left[\mathrm{K}^{+}\right]$in the water ranged from 9 to 78 with a mean value of $39 \pm 10$, similar to natural water.

Sulfate $\left(\mathrm{SO}_{4}{ }^{2-}\right)$ is commonly observed in ground water. The established permissible limit for sulfate is $150 \mathrm{mg} \mathrm{l}^{-1}$ (BIS 2003; WHO 2011). The concentration of $\mathrm{SO}_{4}{ }^{2-}$ in the groundwater of the studied area ranged from 14 to $84 \mathrm{mg} \mathrm{l}^{-1}$ with a mean value of $40 \pm 9 \mathrm{mg} \mathrm{l}^{-1}$. The $\mathrm{SO}_{4}{ }^{2-}$ content in water has a fair correlation $(r=0.80)$ with the $\mathrm{NO}_{3}{ }^{-}$and $\mathrm{Cl}^{-}$content, suggesting origin from a similar sources.

Nitrate $\left(\mathrm{NO}_{3}{ }^{-}\right)$is the most frequently detected drinkingwater contaminant in this region, and nitrate levels of less than $0.2 \mathrm{mg}^{-1}$ are considered to represent background levels. Concentrations ranging from 0.21 to $3.0 \mathrm{mg} \mathrm{l}^{-1}$ are considered transitional. Concentrations between 3.1 and $10 \mathrm{mg} \mathrm{l}^{-1}$ represent elevated concentrations due to human activities. The $\mathrm{NO}_{3}{ }^{-}$concentration in the water of the studied area ranged from 2.7 to $134 \mathrm{mg} \mathrm{l}^{-1}$ with a mean value of $28 \pm 14 \mathrm{mg} \mathrm{l}^{-1}$. The water of $20 \%$ tube wells was contaminated with $\mathrm{NO}_{3}{ }^{-}$beyond the permissible limit of $45 \mathrm{mg} \mathrm{l}^{-1}$ (BIS 2003; WHO 2011).

Iron $(\mathrm{Fe})$ concentrations commonly exceeded the recommended limit of $0.3 \mathrm{mg}^{-1}$ in all tube wells (BIS 2003; WHO 2011). The Fe concentration ranged from 0.90 to $2.25 \mathrm{mg} \mathrm{l}^{-1}$ with mean value of $1.63 \pm 0.20 \mathrm{mg} \mathrm{l}^{-1}$.

Arsenic concentrations in water of all tube wells were above the WHO drinking water guideline value (10 $\mathrm{g} \mathrm{l}^{-1}$ ), ranging from 148 to $985 \mu \mathrm{g} \mathrm{l}^{-1}$ with a mean value of $506 \pm 118 \mu \mathrm{g} \mathrm{l}^{-1}$ (WHO 2011).

\section{Seasonal variations}

The $\mathrm{pH}$ value in the pre-monsoon period (summer season) was found to increase slightly in the range of 6.7-8.3 with a mean value of $7.2 \pm 0.2$ due to slight increase of alkaline nature of the ground water. The concentrations of As, $\mathrm{F}^{-}$,
$\mathrm{Cl}^{-}, \mathrm{SO}_{4}{ }^{2-}, \mathrm{Na}^{+}, \mathrm{K}^{+}, \mathrm{Mg}^{2+}, \mathrm{Ca}^{2+}$ and $\mathrm{Fe}$ increased up to $41,36,14,38,26,39,43,23$ and $69 \%$, respectively, in the pre-monsoon period 2011, possibly due to lowering of the water table and increasing water temperature $\left(\approx 27-29{ }^{\circ} \mathrm{C}\right)$ (Fig. 2). However, the concentration of the $\mathrm{NO}_{3}{ }^{-}$in the pre-monsoon period was decreased $(21 \%)$ probably due to limited anthropogenic inputs.

\section{Water quality and toxicity}

The concentrations of $\mathrm{F}^{-}$, As and $\mathrm{Fe}$ were several folds higher than the values recommended by the WHO. Several cases of arsenic poisoning, i.e., hypopigmentation, melanosis, keratosis, etc., in people of Kaurikasa area have been reported. Chronic exposure to fluoride contaminated water has led to development of skin, dental and skeleton fluorosis in humans and domestic animals. The Water Quality Index (WQI) value for 20 groundwater tube wells ranged from 90 to 317 with a mean value of $172 \pm 28$, indicating unsuitability for drinking purpose.

The value of exchangeable sodium ratio (ESR), sodium hazard $(\mathrm{SH})$ and magnesium hazard $(\mathrm{MH})$ values of the water ranged from 12 to $42 \%, 12$ to $47 \%$ and 25 to $56 \%$ with a mean value of $24 \pm 3 \%, 25 \pm 4 \%$ and $44 \pm 3 \%$, respectively. The water of the studied area was found to be strongly sodic with moderate values of $\mathrm{SH}$ and $\mathrm{MH}$. These
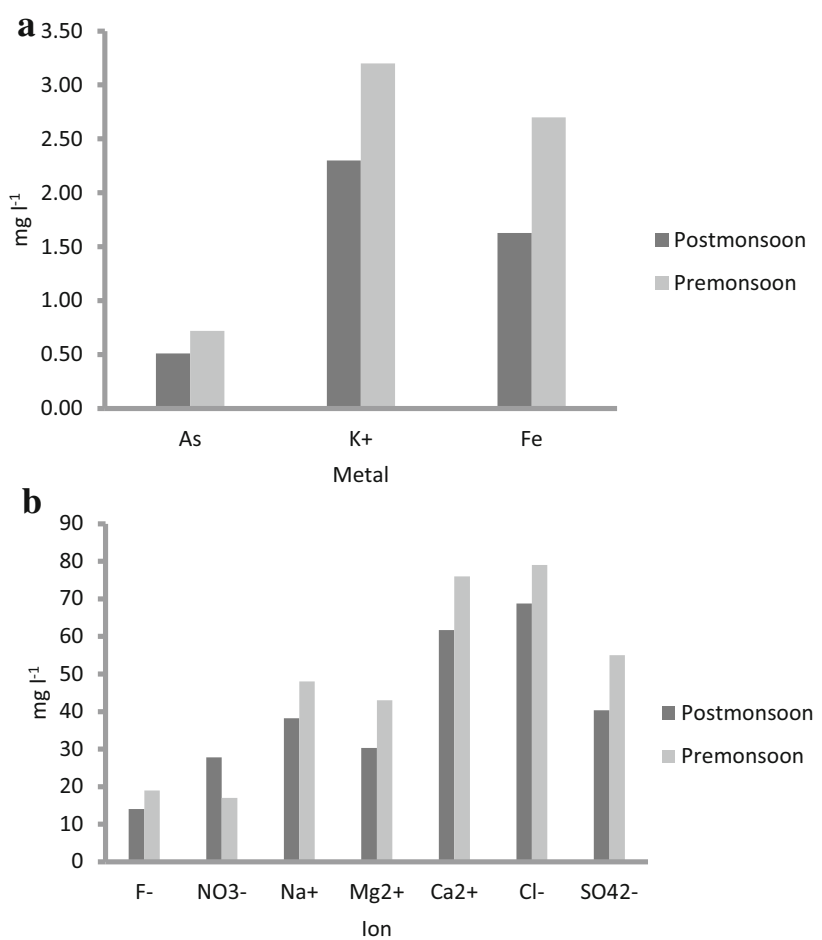

Fig. 2 Seasonal variation of arsenic and other elements in the groundwater 
data reveal that groundwater could be used for irrigation purposes.

\section{Cluster analysis}

Cluster analysis was performed on the dataset by Ward's method using square Euclidean distances as similarity measure (Davies 1986). Figure 3 shows the dendrogram of the physico-chemical characteristics of groundwater in the Ambagarh Chouki. Two groups of parameters are observed. The first group (Group-I) includes major cations (i.e., $\mathrm{Ca}^{2+}, \mathrm{Mg}^{2+}, \mathrm{Na}^{+}$and $\mathrm{K}^{+}$), anions (i.e., $\mathrm{SO}_{4}{ }^{2-}, \mathrm{Cl}^{-}$, $\mathrm{NO}_{3}{ }^{-}$and $\mathrm{F}^{-}$) and the physical parameters (i.e., $\mathrm{pH}, \mathrm{T}$, depth and age), exhibiting strong mutual correlation. The second group (Group-II) contains parameters EC, TDS, $\mathrm{HCO}_{3}{ }^{-}$, As, DOC and $\mathrm{CC}$, which have some relationship with carbon species in groundwater. This suggests that high As concentration in groundwater is linked to DOC and, thus, to its redox status.

The dendrogram of groundwater samples also presents two clusters (Fig. 4). Cluster-I comprises the samples from the tube wells TW5, TW7, TW8, TW10-13, TW15-19 (12 tube wells). Cluster-II contains the samples from TW1-4, TW6, TW9, TW14 and TW20 (8 tube wells). All the parameters differentiate the two groups of tube well water, except $\mathrm{pH}, \mathrm{T}, \mathrm{K}^{+}$and $\mathrm{F}^{-}$. The parameters such as RP, DO, EC, TDS, As, Fe, OC, $\mathrm{CC}, \mathrm{Na}^{+}, \mathrm{Mg}^{2+}, \mathrm{Ca}^{2+}, \mathrm{Cl}^{-}, \mathrm{SO}_{4}{ }^{2-}$, $\mathrm{NO}_{3}{ }^{-}$and $\mathrm{HCO}_{3}{ }^{-}$have higher median values in cluster-I than cluster-II (Fig. 4).

\section{Factor analysis}

This analysis is a multivariate statistical method, aiming to explain the general relationship between measured variables by computing multivariate factors that may help to

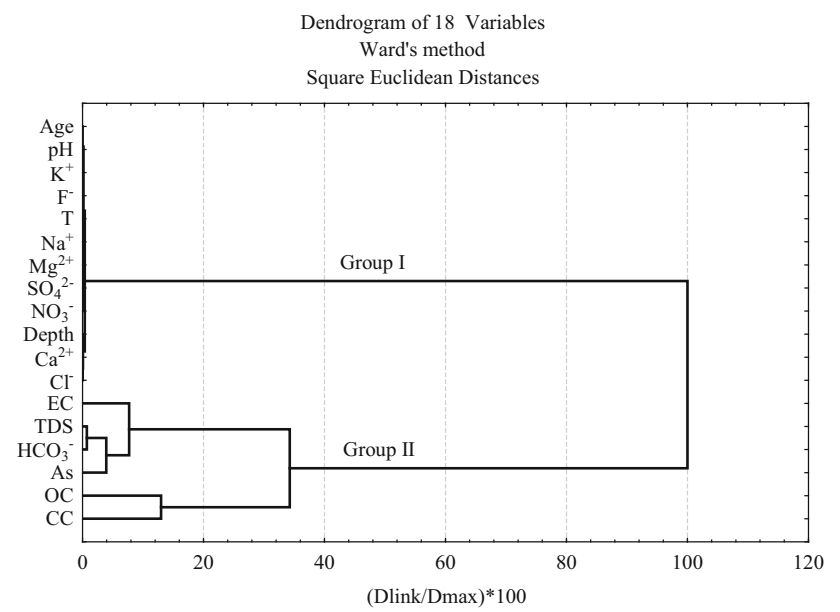

Fig. 3 Dendrogram of the physico-chemical characteristics of groundwater in Ambagarh Chouki

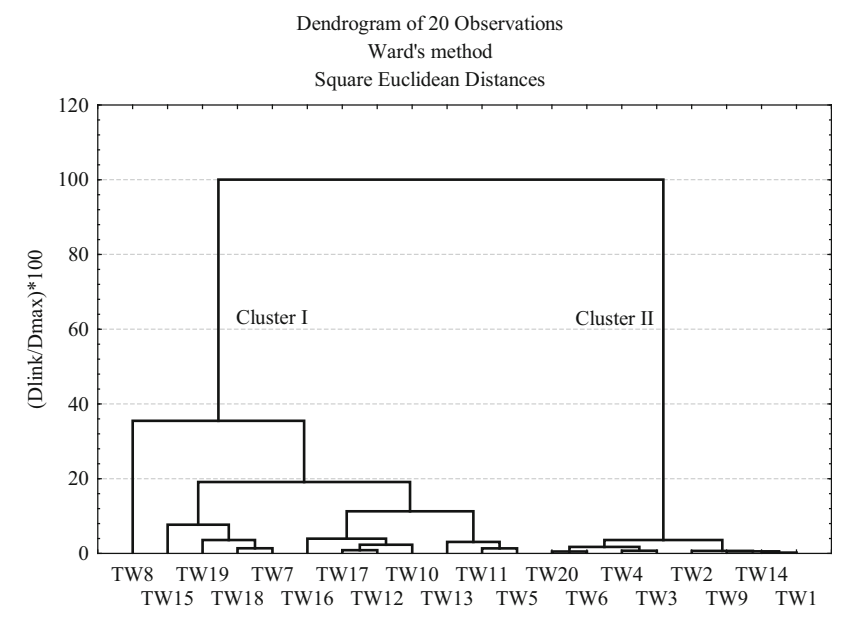

Fig. 4 Dendrogram of sampling sites in Ambagarh Chouki (TW Tube Well)

better classify the original data. Eighteen variables were included in this analysis. First, the raw data were standardized which gave the mean and variance of the variables equal to zero and one, respectively. In reference to the eigenvalues, five factors were extracted after varimax rotation as they have eigenvalues greater than 1 (Kaiser 1958). Table 3 presents the eigenvalues, the percentage of variance and the cumulative percentage of variance associated with each factor. The terms "strong", "moderate" and "weak" were applied to factor loadings, referring to absolute loading values of $>0.70,0.70-0.50$ and $0.50-0.30$, respectively. Factor- 1 explains $42.37 \%$ of the total variance (Table 3 ) and has strong positive loadings on EC, TDS, $\mathrm{Mg}^{2+}, \mathrm{Ca}^{2+}, \mathrm{Cl}^{-}$and $\mathrm{SO}_{4}{ }^{2-}$. The $\mathrm{EC}$ values are positively well correlated with the content of anions and cations. Thus, Factor-1 can reflect the mineralization of the groundwater.

Factor-2 accounts for $13.56 \%$ of the total variance and has high positive loading on depth and high negative loading on $\mathrm{F}^{-}$. These values show that the two parameters are in opposite relation, i.e., $\mathrm{F}^{-}$concentration decreases with depth of wells.

Factor-3 accounts for $10.24 \%$ of the total variance and has strong positive loadings on DOC, CC and a moderate loading on As. A moderate correlation exists between As and $\mathrm{Na}^{+}, \mathrm{Mg}^{2+}, \mathrm{Ca}^{2+}, \mathrm{Cl}^{-}, \mathrm{SO}_{4}{ }^{2-}, \mathrm{NO}_{3}{ }^{-}, \mathrm{HCO}_{3}{ }^{-}, \mathrm{OC}$, and $\mathrm{CC}$ $(0.48 \leq r \leq 0.63)$. Factor- 3 is related to DOC, a controlling factor of $\mathrm{CC}$ content in the groundwater. Complex processes could be related to Factor-3, such as mobilization of As by reductive dissolution (Liu et al. 2003).

Factor-4 accounts for $7.98 \%$ of the total variance and has a strong loading on age of wells and a moderate loading on $\mathrm{K}^{+}$. No significant correlation exists between $\mathrm{K}^{+}$and others major ions. This suggests that $\mathrm{K}^{+}$is derived mostly from K-feldspar dissolution (Jalali 2007). Factor-4 may 
Table 3 Eigen values, percent of variance, cumulative percent of variance for the factor analysis of hydro chemical data in Central India

\begin{tabular}{|c|c|c|c|c|c|}
\hline Parameter & Factor 1 & Factor 2 & Factor 3 & Factor 4 & Factor 5 \\
\hline Age & 0.09 & 0.03 & -0.09 & -0.87 & -0.04 \\
\hline Depth & -0.06 & 0.78 & 0.17 & 0.26 & 0.04 \\
\hline $\mathrm{T}$ & 0.11 & 0.12 & 0.04 & 0.18 & 0.85 \\
\hline $\mathrm{pH}$ & -0.07 & -0.66 & -0.18 & 0.05 & -0.31 \\
\hline $\mathrm{EC}$ & 0.94 & -0.18 & 0.13 & -0.08 & 0.11 \\
\hline TDS & 0.95 & -0.18 & 0.13 & -0.08 & 0.12 \\
\hline As & 0.41 & 0.22 & 0.56 & -0.06 & 0.51 \\
\hline $\mathrm{Na}^{+}$ & 0.47 & 0.27 & 0.47 & -0.30 & 0.35 \\
\hline $\mathrm{K}^{+}$ & 0.03 & -0.01 & 0.48 & -0.68 & -0.06 \\
\hline $\mathrm{Mg}^{2+}$ & 0.93 & -0.08 & 0.02 & 0.07 & 0.14 \\
\hline $\mathrm{Ca}^{2+}$ & 0.93 & 0.06 & 0.08 & -0.18 & 0.19 \\
\hline $\mathrm{F}^{-}$ & 0.14 & -0.80 & 0.14 & 0.28 & 0.14 \\
\hline $\mathrm{Cl}^{-}$ & 0.92 & -0.02 & 0.15 & 0.00 & 0.16 \\
\hline $\mathrm{SO}_{4}{ }^{2-}$ & 0.86 & 0.23 & 0.28 & 0.01 & 0.15 \\
\hline $\mathrm{NO}_{3}^{-}$ & 0.57 & 0.10 & -0.11 & 0.01 & 0.64 \\
\hline $\mathrm{HCO}_{3}^{-}$ & 0.45 & -0.27 & 0.27 & -0.30 & 0.61 \\
\hline $\mathrm{OC}$ & 0.02 & 0.00 & 0.86 & -0.17 & 0.05 \\
\hline $\mathrm{CC}$ & 0.27 & 0.13 & 0.84 & 0.16 & 0.01 \\
\hline Eigen value & 7.60 & 2.53 & 1.83 & 1.41 & 1.17 \\
\hline$\%$ Variance & 42.23 & 14.06 & 10.19 & 7.85 & 6.51 \\
\hline$\%$ Cumulative & 42.23 & 56.29 & 66.48 & 74.33 & 80.84 \\
\hline
\end{tabular}

Absolute loading values $>0.70$, significant at $p<0.05$

The bold values indicates the stronger factor loading $(>0.7)$

represent the dissolution of $\mathrm{K}$-minerals (or $\mathrm{K}$-feldspars) which is related to the age of tube wells.

Factor-5 accounts for $6.68 \%$ of the total variance and has a strong loading on temperature, $\mathrm{T}$. The correlation between $\mathrm{T}$ and As is weak $(r=0.48, p<0.05)$. Temperature is a parameter which could control the rate of some processes such as the release of As by reductive dissolution into groundwater.

\section{Conclusions}

The toxic elements, i.e., As and $\mathrm{F}^{-}$occur in several folds higher concentrations than the WHO permissible limits. The ground water mineralization also comprises species such as $\mathrm{Mg}^{2+}, \mathrm{Ca}^{2+}, \mathrm{Cl}^{-}$and $\mathrm{SO}_{4}^{2}$. In addition, the groundwater is strongly sodic in nature with high WQI value. These hydrochemical data indicate that the groundwater is unsuitable for human consumption. Factor analysis yielded five factors, which were linked to water chemistry-forming processes. Fluoride contamination of the groundwater seems to be related to the tube wells installed at shallow depth and, thus, to enrichment of shallow ground water by evaporation. The presence of As in groundwater seems to be caused by reductive dissolution linked to the presence of dissolved organic matter.

Open Access This article is distributed under the terms of the Creative Commons Attribution 4.0 International License (http:// creativecommons.org/licenses/by/4.0/), which permits unrestricted use, distribution, and reproduction in any medium, provided you give appropriate credit to the original author(s) and the source, provide a link to the Creative Commons license, and indicate if changes were made.

\section{References}

Acharyya SK (2002) Arsenic contamination in groundwater affecting major parts of southern West Bengal and parts of western Chhattisgarh: source and mobilization process. Curr Sci 82:740-744

Acharyya SK, Ashyiya ID, Pandey Y, Lahiri S, Khongan VW, Sarkar SK (2001) Arsenic contamination in groundwater in parts of Ambagarh Chowki-Korse Kohari belt (Dongargarh-Kotri rift zone), Chhattisgrah. Geol Surv India Spec Publ 65:7-18

Acharyya SK, Shah BA, Ashyiya ID, Pandey Y (2005) Arsenic contamination in groundwater from parts of Ambagarh-Chowki block, Chhattisgarh, India: source and release mechanism. Environ Geol 49:148-158

Agusa T, Kunito T, Fujihara J, Kubota R, Minh TB, Trang PTK, Iwata H, Subramanian A, Viet PH, Tanabe S (2006) 
Contamination by arsenic and other trace elements in tube-well water and its risk assessment to humans in Hanoi, Vietnam. Environ Pollut 139:95-106

APHA (2005) Standard methods for the examination of water and wastewater, 21st edn. APHA-AWWA-WEF, Washington

Baig JA, Kazi TG, Arain MB, Afridi HI, Kandhro GA, Sarfraz RA, Jamal MK, Shah AQ (2009) Evaluation of arsenic and other physico-chemical parameters of surface and ground water of Jamshoro, Pakistan. J Hazard Mater 166(2-3):662-669

BIS (2003) Indian standard drinking water specifications IS10500:1991, edition 2.2 (2003-2009), Bureau of Indian Standard, New Delhi

Boyacioglu H, Boyacioglu H (2008) Water pollution sources assessment by multivariate statistical methods in the Tahtali Basin, Turkey. Environ Geol 54:275-282

Chakraborti D, Biswas BK, Roy Chowdhury T, Basu GK, Mandal BK, Chowdhury UK, Mukherjee SC, Gupta JP, Chowdhury SR, Rathore KC (1999) Arsenic groundwater contamination and sufferings of people in Rajnandgaon district, Madhya Pradesh, India. Curr Sci 77:502-504

Chakraborti D, Mukherjee SC, Pati S, Sengupta MK, Rahman MM, Chowdhury UK, Lodh D, Chanda CR, Chakraborti AK, Basu GK (2003) Arsenic groundwater contamination in Middle Ganga Plain, Bihar, India: a future danger? Environ Health Perspect 111(9):1194-1201

Chatterjee A, Mukherjee A (1999) Hydrogeological investigation of ground water arsenic contamination in South Calcutta. Sci Total Environ 225:249-262

Chatterjee D, Halder D, Majumder S, Biswas A, Nath B, Bhattacharya P, Bhowmick S, Mukherjee-Goswami A, Saha D, Hazra R, Maity PB, Chatterjee D, Mukherjee A, Bundschuh J (2010) Assessment of arsenic exposure from groundwater and rice in Bengal Delta Region, West Bengal, India. Water Res 44(19):5803-5812

Chauhan VS, Nickson RT, Chauhan D, Iyengar L, Sankararamakrishnan N (2009) Groundwater geochemistry of Ballia district, Uttar Pradesh, India and mechanism of arsenic release. Chemosphere 75(1):83-91

Davies JC (1986) Statistics and data analysis in Geology. Wiley, New York

Deshpande L, Tijare R, Jashudhar D (2010) Arsenic contamination in groundwater of village in Rajnandgaon district (Chhattisgarh). J Indian Water Works Assoc 42:132-135

Dufor CN, Becker E (1964) Public water supplies of the 100 largest cities in the United States, 1962: U.S. geological survey, water supply paper 1812

Dutta RK, Saikia G, Das B, Bezbaruah C, Das HB, Dube SN (2006) Fluoride contamination in groundwater of Central Assam, India. Asian J Water Environ Pollut 3:93-100

Flanagan SV, Johnston RB, Zheng Y (2012) Arsenic in tube well water in Bangladesh: health and economic impacts and implications for arsenic mitigation. Bull World Health Organ 90:839-846

Hileman B (1988) Fluoridation of water: questions about health risks and benefits remain after more than 40 years. Chem Eng News 66:26-42

Jalali M (2007) Hydrochemical identification of groundwater resources and their changes under the impacts of human activity in the Chah basin in western Iran. Environ Monit Assess 130:347-364

Jha SK, Nayak AK, Sharma YK (2010) Potential fluoride contamination in the drinking water of Marks Nagar, Unnao district, Uttar Pradesh, India. Environ Geochem Health 32:217-226

Kaiser HF (1958) The varimax criterion for analytic rotation in factor analysis. Psychometrika 23:187-200
Kar S, Maity JP, Jean JS, Liu CC, Nath B, Yang HJ, Bundschuh J (2010) Arsenic-enriched aquifers: occurrences and mobilization of arsenic in groundwater of Ganges Delta Plain, Barasat, West Bengal, India. Appl Geochem 25(12):1805-1814

Krishnamurthy P, Chaki A, Sinha RM, Singh SN (1988) Geology, geochemistry and genesis of metabasalts, metarhyolites and the associated uranium mineralization at Bodal, Rajnandgaon district, Madhya Pradesh and implications for uranium exploration in central India. Explo Res Atom Min 1:13-39

Kumar M, Kumar P, Ramanathan AL, Bhattacharya P, Thunvik R, Singh UK, Tsujimura M, Sracek O (2010) Arsenic enrichment in groundwater in the middle Gangetic Plain of Ghazipur District in Uttar Pradesh, India. J Geochem Explor 105:83-94

Kundu MC, Mandal B (2009) Assessment of potential hazards of fluoride contamination in drinking groundwater of an intensively cultivated district in West Bengal, India. Environ Monit Assess 152:97-103

Liu CW, Lin KH, Kuo YM (2003) Application of factor analysis in the assessment of groundwater quality in a blackfoot disease area in Taiwan. Sci Total Environ 313:77-89

Meenakshi, Maheshwari RC (2006) Fluoride in drinking water and its removal. J Hazard Mater 137(1):456-463

Nielsen DM, Nielsen GL (2006) The essential handbook of groundwater sampling. CRC Press, Boca Raton

Nollet L ML, De Gelder L SP (2007) Handbook of water analysis, 2nd edn. CRC Press, Boca Raton

Pandey PK, Khare RN, Sharma R, Sar SK, Pandey M, Binayake P (1999) Arsenicosis and deteriorating groundwater quality: unfolding crisis in central east Indian region. Curr Sci 77:686-693

Pandey PK, Yadav S, Nair S, Bhui A (2002) Arsenic contamination of the environment: a new perspective from central-east India. Environ Int 28:235-245

Pandey PK, Sharma R, Roy M, Roy S, Pandey M (2006) Arsenic contamination in the Kanker district of central-east India: geology and health effects. Environ Geochem Health 28:409-420

Patel KS, Shrivas K, Brandt R, Jakubowski N, Corns W, Hoffmann P (2005) Arsenic contamination in water, soil, sediment and rice of central India. Environ Geochem Health 27:131-145

Reddy DV, Nagabhushanam P, Sukhij BS, Reddy AGS, Smedley PL (2010) Fluoride dynamics in the granitic aquifer of the Wailapally watershed, Nalgonda District, India. Chem Geol 269(3-4):278-289

Rodríguez-Lado L, Sun G, Berg M, Zhang Q, Xue H, Zheng Q, Johnson CA (2013) Groundwater arsenic contamination throughout China. Science 341(6148):866-868

Sankararamakrishnan N, Sharma AK, Iyengar L (2008) Contamination of nitrate and fluoride in ground water along the Ganges Alluvial Plain of Kanpur district, Uttar Pradesh, India. Environ Monit Assess 146:375-382

Sarkar SN (1957) Stratigraphy and tectonics of Dongargarh system: a new system in the Precambrians of Bhandera-Durg-Balaghat area, Bombay and MP. J Sci Eng Res 1:237-268

Shukla DP, Dubey CS, Singh NP, Tajbakhsh M, Chaudhry M (2010) Sources and controls of arsenic contamination in groundwater of Rajnandgaon and Kanker District, Chattisgarh, Central India. J Hydrol 395:49-66

Simeonov V, Stratis JA, Samara C, Zachariadis G, Voutsa D, Anthemidis A, Sofoniou M, Kouimtzis T (2003) Assessment of surface water quality in northern Greece. Water Res $37: 4119-4124$

Singh B, Gaur S, Garg VK (2007) Fluoride in drinking water and human urine in southern Haryana, India. J Hazard Mater 144:147-151 
Suthar S, Garg VK, Jangir S, Kaur S, Goswami N, Singh S (2008) Fluoride contamination in drinking water in rural habitations of Northern Rajasthan, India. Environ Monit Assess 145(1-3):1-6

WHO (2011) Guidelines for drinking water quality, 4th edn. World Health Organization, Geneva

Winkel LHE, Trang PTK, Lan VM, Stengel C, Amini M, Ha NT, Viet PH, Berg M (2011) Arsenic pollution of groundwater in Vietnam exacerbated by deep aquifer exploitation for more than a century. PNAS 108:1246-1251

Yadav JP, Lata S, Kataria SK, Kumar S (2009) Fluoride distribution in groundwater and survey of dental fluorosis among school children in the villages of the Jhajjar district of Haryana, India. Environ Geochem Health 31:431-438 